\title{
PANDANGAN HUKUM EKONOMI SYARIAH TERHADAP HARGA LELANG BARANG JAMINAN
}

\author{
Arzalsyah Syarief
}

Fakultas Ekonomi Universitas Andi Djemma

\begin{abstract}
In the perspective of Islamic Economics auction collateral, is permitted with a note using the pillars of purchase, the terms of buying and selling and general conditions of sale and purchase, ranging from notice to customers that the goods are used as collateral has passed the due time, notice the condition of goods such guarantees, tender preparation until the results of the auction the collateral. Then the auction price realized collateral and must fulfill the will of rapprochement agreement between the seller and the buyer. The auction fee charged to the buyer is not intended to raise the price, but for the interests of the State and the fund will be used as a tax. while in the process of being auctioned pledge collateral offered to customers who first did a deal with the official sanctioning body in this case sharia pawnshops
\end{abstract}

Keyword: Auction Price Of Warranty

\begin{abstract}
Abstrak
Dalam perspektif agunan lelang Ekonomi Islam, diizinkan dengan catatan menggunakan pilar pembelian, ketentuan jual beli dan kondisi umum jual beli, mulai dari pemberitahuan kepada pelanggan bahwa barang yang digunakan sebagai jaminan telah melewati batas waktu waktu, perhatikan kondisi barang jaminan tersebut, persiapan tender hingga hasil lelang agunan. Kemudian harga lelang direalisasikan agunan dan harus memenuhi keinginan perjanjian pemulihan hubungan antara penjual dan pembeli. Biaya lelang yang dibebankan kepada pembeli tidak dimaksudkan untuk menaikkan harga, tetapi untuk kepentingan Negara dan dana akan digunakan sebagai pajak. sedangkan dalam proses lelang dijaminkan jaminan yang ditawarkan kepada pelanggan yang pertama kali melakukan kesepakatan dengan badan sanksi resmi dalam hal ini pegadaian syariah
\end{abstract}

Kata Kunci : Lelang Barang Jaminan

\section{PENDAHULUAN}

Dalam rangka menunjang pelaksa-naan kebijaksanaan dan program pemerintah di bidang ekonomi dan pembangunan nasional pada umumnya, salah satu sektor yang perlu mendapat perhatian serius adalah lembaga jaminan. Perkembangan ekonomi akan diikuti oleh perkembangan kebutuhan kredit atau pinjaman baik itu untuk kegiatan perindustrian, perdagangan, perseroan mau-pun untuk memenuhi kebutuhan 
hidup sehari-hari. Kegiatan-kegiatan tersebut di atas memerlukan fasilitas kredit atau pinjaman dalam usahanya dan membutuh-kan adanya jaminan bagi pemberi kredit demi keamanan pemberian kredit.

Manusia merupakan makhluk sosial, yang artinya manusia tidak bisa hidup sendiri dalam memenuhi kebutuhan untuk mempertahankan hidupnya. Oleh sebab itu, sudah seharusnya manusia saling tolong menolong. Disadari atau tidak, dalam hidup bermasyarakat manusia selalu berhubungan satu dengan yang lainnya. Hal ini disebabkan karena pada suatu saat seseorang memiliki sesuatu yang dibutuhkan orang lain, sedangkan orang lain membutuhkan sesuatu yang dimiliki seseorang tersebut, sehingga terjadilah hubungan saling mem-beri dan menerima. (Q.S. Al-Maidah /5 : 2)

Untuk melaksanakan pembangunan ekonomi dan untuk meningkatkan semangat masyarakat dalam melakukan kegiatan ekonomi, pemerintah telah menyediakan berbagai fasilitas kredit atau pinjaman Bentuk fasilitas kredit atau pinjaman yang disediakan pemerintah antara lain melalui bank-bank pemerintah, kemudian diikuti oleh bank swasta yang ikut berperan besar dalam pelayanan pemberian kredit kepada masyarakat.

Sebagaimana perekonomian sebagai salah satu sokoguru kehidupan negara. Perekonomian negara yang kokoh juga akan mampu menjamin kesejahteraan rakyat. Untuk itu Allah swt. memberi inspirasi kepada mereka untuk mengadakan penukar-an dan semua yang kiranya bermanfaat dengan jalan jual beli, sehingga hidup manusia dapat berdiri dengan lurus dan bekerja dengan baik dan produktif. Dengan berkembangnya teknologi telah mendorong masyarakat untuk mengadakan spesialisasi produksi. Dalam tingkatan ini orang tidak lagi memproduksi untuk dirinya sendiri, melainkan mereka memproduksi untuk pasar. Dalam hal ini muncul peranan jual beli atau perdagangan. ${ }^{1}$

\footnotetext{
${ }^{1}$ A. M. Syaefuddin, Islam untuk Disiplin Ilmu Ekonomi, (Jakarta: Dirjen Lembaga Islam Depag RI 1997), h. 93.
} 
Jual beli secara umum adalah suatu perjanjian, dengan perjanjian itu kedua belah pihak mengatakan dirinya untuk menyerah-kan hak milik atas suatu barang dan pihak yang lain membayar harga yang telah dijanjikan. Perdagangan atau jual beli dapat dilakukan dengan langsung dan dapat pula dengan lelang. Cara jual beli dengan sistem lelang dalam fiqih disebut Muzayadah. ${ }^{2}$

Salah satu lembaga perkreditan non perbankan yang dapat melayani masyarakat guna untuk mendapatkan kredit dengan mudah yaitu Perusahaan Umum Pegadaian. Perum Pegadaian merupakan lembaga per-kreditan yang dikelola oleh pemerintah yang kegiatan utamanya melaksanakan penyalu-ran uang pinjaman atas dasar hukum gadai. Penyaluran uang pinjaman tersebut dilaku-kan dengan cara yang mudah, cepat, dan aman sehingga tidak memberatkan bagi masyarakat yang melakukan pinjaman dan tidak menimbulkan masalah yang baru bagi peminjam setelah melakukan pinjaman di pegadaian. Hal tersebut sesuai dengan motto yang digunakan pegadaian yaitu "Mengatasi Masalah Tanpa Masalah".

Pada kenyataannya perum pegadaian merupakan lembaga perkreditan yang sangat dibutuhkan oleh masyarakat khususnya golongan ekonomi menengah ke bawah. Kelebihan perusahaan umum pegadaian ini bagi masyarakat yang meminjam kredit adalah pihak yang berkepentingan tidak perlu menjual barang-barangnya, melainkan hanya dijadikan jaminan pengajuan kredit di perusahaan umum pegadaian.

Berdasarkan kenyataan di atas, maka peran pegadaian sebagai lembaga pembiaya-an dalam era sekarang dan masa akan datang tetap penting untuk mewujudkan pember-dayaan ekonomi rakyat baik di kota maupun di pedesaan. Dalam kondisi seperti ini peranan pegadaian sebagai jaring pengaman sosial bagi masyarakat kecil semakin penting untuk menyediakan kredit berskala kecil, cepat, bunga ringan dan tidak berbelit. Adapun tujuan pegadaian adalah untuk memberikan jaminan bagi pemegang gadai bahwa di kemudian hari piutangnya pasti dibayar dari nilai jaminan.

\footnotetext{
${ }^{2}$ Imam Ash-Shan'ani, Subulus Salam Juz. III, (Beirut: Darul Kutub Al-Ilmiyah, 1995), h. 23.
} 
Pegadaian dalam menyalurkan kredit kepada masyarakat dengan jaminan bendabenda bergerak. Benda bergerak tersebut harus memiliki nilai jual yang sama dengan uang yang dibutuhkan oleh yang berhutang tersebut. Karena benda bergerak ini memiliki nilai yang sama dengan uang yang dipinjam oleh orang yang bersangkutan, maka benda ini dapat dijadikan sebagai jaminan dari hutang tersebut. Jadi pada dasarnya gadai diberikan untuk menjamin suatu tagihan atau kredit. Di dalam per-janjian gadai, apabila debitur wanprestasi atau tidak dapat melunasi hutang-hutangnya atau tidak mampu menebus barangnya sampai habis jangka waktu yang telah ditentukan, maka pihak pegadaian berhak untuk melelang barang gadai tersebut dan hasil dari penjualan lelang tersebut sebagian untuk melunasi hutang kreditnya, membayar sewa modal sebagian lagi untuk biaya yang dikeluarkan untuk melelang barang tersebut dan sisanya diberikan kepada si pemberi gadai. Maka dari itu harga dari penjualan lelang harus diperhitungkan sesuai dengan prosedur untuk mendapatkan harga lelang yang seharusnya dan tidak merugikan pihak manapun yang berbasis keadilan, yaitu harga yang digunakan harus adil.

Islam mengartikan harga sebagai harga yang adil yaitu harga yang diserahkan pada keseimbangan pasar. ${ }^{3}$ Harga diserah-kan kepada hukum pasar untuk memainkan perannya secara wajar, sesuai dengan pena-waran dan permintaan yang ada. ${ }^{4}$ Kesalahan dalam penentuan harga dapat menimbulkan berbagai konsekuensi dan dampaknya jauh. Tindakan penetapan harga yang melanggar etika dapat menyebabkan para pelaku usaha tidak disukai para pembeli, bahkan para pembeli dapat melakukan suatu reaksi yang dapat menjatuhkan nama baik pelaku usaha. Apabila kewenangan harga tidak berada pada pelaku usaha melainkan berada pada kebijakan pemerintah, maka penentuan harga yang tidak diinginkan oleh para pem-beli (dalam hal ini sebagian masyarakat) bisa mengakibatkan suatu reaksi penolakan oleh banyak orang/kalangan.

\footnotetext{
${ }^{3}$ Dyana Harahap, Definisi Harga Menurut Islam, http://hargayangadil. blogspot. com/2011/02 /definisi-harga-menurut-islam.html. diakses 20 September 2015.

${ }^{4}$ Yusuf Qardawi, Halal Haram Dalam Islam, (Solo: Era Intermedia,2003), h.357.
} 
Sebagaimana jual beli dalam kasus lelang, dalam pematokan harga banyak triktrik kotor berupa komplotan lelang dan komplotan penawar yaitu sekelompok pembeli dalam lelang yang bersekongkol untuk menawar dengan harga rendah, dan jika berhasil kemudian dilelang sendiri di antara mereka. Pasar lelang didefinisikan sebagai suatu pasar terorganisir, di mana harga menyesuaikan diri terus menerus terhadap penawaran dan permintaan, serta biasanya dengan barang dagangan standar, jumlah penjual dan pembeli cukup besar dan tidak saling mengenal. Menurut ketentuan yang berlaku di pasar tersebut, pelaksanaan lelang dapat menggunakan persyaratan tertentu seperti si penjual dapat menolak tawaran yang dianggapnya terlalu rendah yaitu dengan memakai batas harga terendah/ cadangan atau harga bantingan. Segala bentuk rekayasa curang untuk mengeruk keuntungan tidak sah dalam praktik lelang dikategorikan para ulama dalam praktik najasy yang diharamkan Nabi saw, atau juga dapat dimasukkan dalam kategori Risywah (sogok) bila penjual atau pembeli meng-gunakan uang, fasilitas ataupun servis untuk memenangkan lelang yang sebenarnya tidak memenuhi kriteria yang dikehen-daki mitra bisnisnya. Dalam praktiknya, tidak jarang terjadi penyimpangan prinsip syariah seperti manipulasi, kolusi maupun per-mainan kotor lainnya. Permasalahan harga memang meru-pakan masalah yang berada di antara dua aspek yang berbeda yaitu dari aspek bisnis dan aliran agama yang mengatur segala bentuk hal yang ada dalam kehidupan manusia.

\section{KONSEPSI TENTANG HARGA}

Harga adalah salah satu unsur bauran pemasaran yang menghasilkan pendapatan, unsur-unsur lainnya menghasilkan biaya. Harga adalah unsur bauran pemasaran yang paling mudah disesuaikan; ciri-ciri produk, saluran, bahkan promosi membutuh-kan lebih banyak waktu. Harga juga meng-komunikasikan posisi nilai yang dimaksud-kan perusahaan tersebut kepada pasar tentang produk dan mereknya. Selain itu dalam teori ekonomi, pengertian harga, nilai dan utility merupakan konsep yang paling berhubungan. Yang dimaksud dengan utility ialah suatu atribut yang melekat 
pada suatu barang, yang memungkinkan barang tersebut dapat memenuhi kebutuhan (needs), ke-inginan (wants) dan memuaskan konsumen (satisfaction).

Menurut para ekonom, harga, nilai, dan faedah/manfaat (utility) merupakan konsep-konsep yang berkaitan. Utility adalah atribut suatu produk yang dapat memuaskan kebutuhan, sedangkan nilai adalah ungkapan secara kuantitatif tentang kekuatan barang untuk dapat menarik barang lain dalam pertukaran. Dalam perekonomian sekarang ini untuk mengadakan pertukaran atau mengukur nilai suatu produk meng-gunakan uang, bukan sistem barter. Jumlah uang yang digunakan dalam pertukaran tersebut mencerminkan tingkat harga dari suatu barang tersebut. Jadi, harga adalah sejumlah uang yang dibutuhkan untuk mendapatkan sejumlah kombinasi dari produk dan pelayanannya. ${ }^{5}$

Dalam Islam, harga dikenal dengan harga yang adil, hal ini juga mendapat perhatian banyak pemikir dunia termasuk dunia barat. Penulis jerman Rudolf Kaulla menyatakan konsep tentang justum pretium (harga yang adil), mula-mula konsep ini dilaksanakan di Roma dengan latar bela-kang pentingnya menerapkan atau menempatkan aturan khusus untuk memberi petunjuk dalam kasus-kasus yang dihadapi hakim, di mana dengan tatanan itu, dia menetapkan nilai-nilai dari sebuah barang dagangan atau jasa. Pernyataan ini hanya menggambarkan sebagian cara harga dibentuk dengan pertimbangan etika dan hukum. ${ }^{6}$

Ilmuwan pada abad pertengahan yang pemikirannya tentang harga banyak menjadi pijakan pemikiran di masa berikutnya adalah St. Thomas Aquinus tanpa secara eksplisit menjelaskan definisi harga yang adil ia mengatakan "sangat berdosa mempraktekan penipuan terhadap tujuan penjualan sesuatu yang melebihi dari harga yang adil, karena itu sama dengan men-curangi tetangganya agar menderita ke-rugian”. Ia juga mengatakan Harga yang adil itu akan menjadi salah satu hal yang tak hanya dimasukkan dalam perhitungan nilai barang yang dijual, juga bisa mendatangkan

\footnotetext{
${ }^{5}$ Didit Purnomo, Buku Pegangan Kuliah Kebijakan Harga (Pendekatan Agrikultural), Surakarta: FE- UMS, 2005, h. 302.

${ }^{6}$ M. B. Hendri Anto, Pengantar Ekonomi Islam, (Yogyakarta: Ekonisia, 2003), h. 288.
} 
kerugian bagi penjual. Dan juga suatu barang bisa dibolehkan secara hukum dijual lebih tinggi ketimbang nilainya sendiri, meskipun nilainya tak lebih dibanding harga pemiliknya. $^{7}$

Dari sudut pandang pemasaran, harga merupakan satuan moneter atau ukuran lainnya (termasuk barang dan jasa lainnya) yang ditukarkan agar memperoleh hak kepemilikan atau penggunaan suatu barang atau jasa. Dari pengertian di atas dapat dijelaskan bahwa harga merupakan sesuatu ke-sepakatan mengenai transaksi jual beli barang atau jasa di mana kesepakatan ter-sebut diridhai oleh kedua belah pihak. Harga tersebut haruslah direlakan oleh kedua belah pihak dalam akad, baik lebih sedikit, lebih besar, atau sama dengan nilai barang atau jasa yang ditawarkan oleh pihak penjual kepada pihak pembeli.

Dalam terminologi Arab yang makna-nya menuju pada harga yang adil antara lain adalah: si'r al mithl, staman al mithl, dan qimah al adl. Istilah qimah al adl (harga yang adil) pernah digunakan oleh Rasulullah saw. dalam mengomentari kompensasi bagi pembebasan budak, di mana budak menjadi manusia merdeka dan majikannya tetap memperoleh kompensasi dengan harga yang adil. Istilah ini juga ditemukan dalam laporan Khalifah Umar bin Khatab dan Ali bin Abi Thalib. Umar bin Khatab meng-gunakan istilah harga yang adil ini ketika menetapkan nilai baru atas diyat (denda/ uang tebusan darah), setelah nilai dirham turun sehingga harga-harga naik.

Istilah qimah al adl juga banyak digunakan para hakim yang telah mengkodifikasikan hukum Islam tentang transaksi bisnis dalam obyek barang cacat yang dijual, perebutan kekuasaan, memaksa penimbun barang untuk menjual barang timbunannya, membuang jaminan atas atas harta milik dan sebagainya. Secara umum mereka berpikir bahwa harga sesuatu yang adil adalah harga yang dibayar untuk obyek yang sama yang diberikan pada waktu dan tempat diserah-kan. ${ }^{8}$ Konsep harga Islam

\footnotetext{
${ }^{7}$ Ibid, h. 288.

${ }^{8}$ M. B. Hendri Anto, Pengantar Ekonomi Islam, (Yogyakarta: Ekonisia, 2003), h. 286.
} 
juga banyak menjadi daya tarik bagi para pemikir Islam dengan menggunakan kondisi ekonomi di sekitarnya dan pada massanya, pemikir tersebut adalah sebagai berikut ;

\section{Konsep Harga Abu Yusuf}

Abu Yusuf adalah seorang mufti pada kekhalifahan Harun al- Rasyid. Ia menulis buku pertama tentang sistem perpajakan dalam Islam yang berjudul Kitab al-Kharaj. Abu Yusuf tercatat sebagai ulama terawal yang mulai menyinggung mekanisme pasar. Beliau memperhatikan peningkatan dan penurunan produksi dalam kaitannya dengan perubahan harga. Beliau jugalah yang mengajukan pertama kali tentang teori permintaan dan persediaan (demand and supplay) dan pengaruhnya terhadap harga. ${ }^{9}$

Fenomena yang terjadi pada masa Abu Yusuf adalah, ketika terjadi kelangkaan barang maka harga cenderung akan tinggi, sedangkan pada saat barang tersebut melimpah, maka harga cenderung untuk turun atau lebih rendah ${ }^{10}$ hal tersebut dikontradikisikan dengan pendapat Abu Yusuf yang mengatakan bahwa

"Tidak ada batasan tertentu tentang murah dan mahal yang dapat dipasti-kan.

Hal tersebut ada yang mengatur-nya. Prinsipnya tidak bisa diketahui. Murah bukan karena melimpahnya makanan, demikian juga dengan ma-hal tidak disebabkan karena kelang-kaan makanan. Murah dan mahal merupakan ketentuan Allah. Kadang- kadang makanan sangat sedikit tetapi murah.” 11

Pandangan Abu Yusuf di atas menun-jukkan adanya hubungan negatif antara persediaan (supply) dengan harga. Hal ini adalah benar bahwa harga itu tidak tergantung pada supply itu sendiri, oleh karena itu berkurangnya atau bertambahnya harga semata-mata tidak berhubungan dengan ber-tambah atau berkurangnya dalam penawaran. Dalam hal ini, Abu Yusuf tampak-nya menyangkal pendapat umum mengenai hubungan terbalik antara permintaan dengan harga. Pada kenyataannya harga tidak ter-

\footnotetext{
${ }^{9}$ Siti Muflikhatul Hidayah, Penentuan Harga Jual Beli Dalam Ekonomi Islam, (UMS, 2011), h. 70 .

${ }^{10}$ Adiwarman Azwar Karim, Sejarah Pemikiran Ekonomi Islam edisi ketiga, (Jakarta: PT. Raja Grafindo Persada, 2006), h.250.

${ }^{11}$ Muhammad, Ekonomi Mikro Dalam Perspektif Islam, (Yogyakarta: BPFE, 2004), h. 353.
} 
gantung pada penawaran saja tetapi juga permintaan. Abu Yusuf menegaskan bahwa ada variabel lain yang mempengaruhi akan tetapi beliau tidak menjelaskan secara rinci.

Sedangkan pada masalah pengen-dalian harga (tas 'ir). Abu Yusuf menentang penguasa yang menetapkan harga. Menurut-nya harga merupakan ketentuan Allah. Maksudnya adalah harga akan terbentuk sesuai dengan hukum alam yang berlaku di suatu tempat dan waktu tertentu sesuai dengan faktor-faktor yang mempengaruhi harga itu sendiri. Pendapat Abu Yusuf ini relevan pada pasar persaingan sempurna di mana banyak penjual dan banyak pembeli sehingga harga ditentukan oleh pasar.

\section{Konsepsi Harga Ibnu Taimiyah}

Ibnu Taimiyah menjelaskan mengenai mekanisme pertukaran, ekonomi pasar bebas, dan bagaimana kecenderungan harga terjadi sebagai akibat dari kekuatan permintaan dan penawaran. Jika permintaan terhadap barang meningkat sementara penawaran menurun harga akan naik. Begitu sebaliknya, kelangkaan dan melimpahnya barang mungkin disebabkan oleh tindakan yang adil, atau mungkin tindakan yang tidak adil. Hal ini terjadi karena pada masanya ada anggapan bahwa peningkatan harga merupa-kan akibat dari ketidakadilan dan tindakan dari melanggar hukum dari pihak penjual, atau mungkin sebagai akibat manipulasi pasar. Ibnu Taimiyah dalam A. Islahi berkata:

"Naik dan turunnya harga tak selalu berkaitan dengan kezaliman (zulm) yang dilakukan seseorang. Sesekali alasannya adalah adanya kekurangan dalam produksi atau penurunan impor dari barang-barang yang diminta. Jika membutuhkan peningkatan jumlah barang sementara kemampuannya menurun, harga dengan sendirinya akan naik. Di sisi lain, jika kemam-puan penyediaan barang meningkat dan permintaannya menurun, harga akan turun. Kelangkaan dan ke-limpahan tak mesti diakibatkan oleh perbuatan seseorang. Bisa saja berkaitan dengan sebab yang tak melibatkan ketidakadilan. Atau sesekali bisa juga disebabkan ketidakadilan. Maha besar Allah yang menciptakan kemauan pada hati manusia. $^{12}$

\footnotetext{
${ }^{12}$ A. A. Islahi, Konsepsi Ekonomi Ibnu Taimiyah, (Jakarta: Bina Ilmu, 1997), h. 12.
} 
Menurut Ibnu Taimiyah, penawaran bisa datang dari produksi domestik dan impor. Perubahan dalam penawaran digam-barkan sebagai peningkatan atau penurunan dalam jumlah barang yang ditawarkan, sedangkan permintaan sangat ditentukan oleh selera dan pendapatan. ${ }^{13}$ Di sisi lain, Ibnu Taimiyah mengidentifikasi beberapa faktor lain yang menetukan permintaan dan penawaran yang mempengaruhi harga pasar, yaitu:

1) Keinginan masyarakat (raghbah) terhadap berbagai jenis barang yang berbeda dan selalu berubah-ubah. Perubahan ini sesuai dengan langka atau tidaknya barangbarang yang diminta. Semakin sedikit jumlah suatu barang yang tersedia akan semakin diminati masyarakat.

2) Jumlah para peminat terhadap suatu barang. Jika jumlah masyarakat yang meng-inginkan suatu barang tersebut akan semakin meningkat, dan begitu pula sebaliknya.

3) Lemah atau kuatnya kebutuhan ter-hadap suatu barang serta besar atau kecilnya tingkat dan ukuran kebutuhan. Apabila kebutuhan besar dan kuat, harga akan naik. Sebaliknya jika kebutuhan kecil dan lemah harga akan turun. ${ }^{14}$

Jika transaksi telah berjalan sesuai dengan ketentuan yang ada tetapi harga tetap naik, menurut Ibnu Taimiyah ini merupakan kehendak Allah. Maksudnya pelaku pasar bukanlah satu-satunya faktor yang menentukan harga tetapi ada beberapa faktor lain yang mempengaruhi harga, hal ini dapat disebut sebagai proses jual beli.

\section{Konsep Harga Ibnu Khaldun}

Dalam karyanya yang berjudul al Muqoddimah pada bab yang berjudul "harga di kota-kota" ia membagi jenis barang menjadi barang kebutuhan pokok dan mewah. Menurutnya, bila suatu kota ber-kembang dan selanjutnya populasinya akan bertambah banyak, maka harga-harga ke-butuhan pokok akan mendapatkan prioritas pengadaannya. Akibatnya penawaran me-ningkat dan ini berarti turunnya harga.

\footnotetext{
${ }^{13}$ Muhammad, op. cit., h.358.

${ }^{14}$ Adiwarman Azwar Karim, op. cit., h. 366-367.
} 
Sedangkan untuk barang-barang mewah, permintaannya meningkat sejalan dengan berkembangnya kota dan berubahnya gaya hidup. Akibatnya harga barang mewah akan meningkat.

Bagi Ibnu Khaldun, harga adalah hasil dari hukum permintaan dan penawaran. Pengecualian satu-satunya dari hukum ini adalah harga emas dan perak, yang merupakan standar moneter. Semua barang-barang lain terkena fluktuasi harga yang tergantung pada pasar. Bila suatu barang langka dan banyak diminta, maka harganya tinggi. Jika suatu barang berlimpah maka harganya akan rendah. Mekanisme penawaran dan permintaan dalam menentukan harga keseimbangan menurut Ibnu Khaldun, pengaruh persaingan di antara konsumen untuk mendapatkan barang pada sisi permintaan. Setelah itu pada sisi penawaran, ia menjelaskan pula pengaruh meningkatnya biaya produksi karena pajak dan pungutan-pungutan lainnya di kota tersebut. ${ }^{15}$

Hal ini menunjukkan bahwa Ibnu Khaldun, sebagaimana Ibnu Taimiyah telah mengidentifikasi kekuatan permintaan dan penawaran sebagai penentu harga keseimbangan. Ibnu Khaldun kemudian mengata-kan bahwa keuntungan yang wajar akan mendorong tumbuhnya perdagangan, se-dangkan keuntungan yang sangat rendah akan membuat lesu perdagangan karena pedagang kehilangan motivasi. Sebaliknya, jika pedagang mengambil keuntungan sangat tinggi, juga akan membuat lesu perdagangan karena lemahnya permintaan konsumen.

\section{KONSEPSI TENTANG LELANG}

Lelang termasuk salah satu bentuk jual beli, akan tetapi ada perbedaan secara umum. Jual beli ada hak memilih, boleh tukar menukar di muka umum dan sebaliknya, sedangkan lelang tidak ada hak memi-lih, tidak boleh tukar menukar di depan umum, dan pelaksanaannya dilakukan khusus di muka umum. ${ }^{16}$ Jual beli menurut

15 Ibid.

${ }^{16}$ Aiyub Ahmad, Fikih Lelang Perspektif Hukum Islam Dan Hukum Positif, (Jakarta: Kiswah, 2004), h. 3. 
bahasa artinya "menukarkan sesuatu" sedangkan menurut syara' jual beli artinya "menukarkan harta dengan harta menurut cara-cara tertentu (akad)". ${ }^{17}$

Jual beli secara etimologis berarti pertukaran mutlak. Kata al-bai' (jual) dan AsySyiraa' (beli) penggunaannya disama-kan antara keduanya, yang masing-masing mempunyai pengertian lafadz yang sama dan pengertian berbeda. Dalam syariat Islam, jual beli merupakan pertukaran semua harta (yang dimiliki dan dapat dimanfaatkan) dengan harta lain berdasarkan keridhaan antara keduanya. Atau dengan pengertian lain memindahkan hak milik dengan hak milik orang lain berdasarkan persetujuan dan hitungan materi. ${ }^{18}$

Berdasarkan definisi tersebut dapat dipahami bahwa jual beli adalah suatu bentuk perjanjian. Begitu pula dengan cara jual beli dengan sistem lelang yang dalam penjualan tersebut ada bentuk perjanjian yang akan menghasilkan kata sepakat antara pemilik barang maupun orang yang akan membeli barang tersebut, baik berupa harga yang ditentukan maupun kondisi barang yang diperdagangkan, dalam fiqih disebut Muzayadah. ${ }^{19}$

Secara Umum Lelang adalah penjual-an barang yang dilakukan di depan umum termasuk melalui media elektronik dengan cara penawaran lisan dengan harga yang semakin meningkat atau harga yang semakin menurun dan atau dengan penawar-an harga secara tertulis yang didahului dengan usaha mengumpulkan para peminat. ${ }^{20}$ Lebih jelas-nya lelang menurut pengertian di atas adalah suatu bentuk penjualan barang di depan umum kepada penawar tertinggi. Namun akhirnya penjual akan menentukan, yang berhak membeli adalah yang mengajukan harga tertinggi. Lalu terjadi akad dan pembeli tersebut mengambil barang dari penjual.

Menurut Ibnu Qudamah Ibnu Abdi Dar meriwayatkan adanya ijma' kesepakatan ulama tentang bolehnya jual-beli secara lelang bahkan telah menjadi kebiasaan yang

\footnotetext{
${ }^{17}$ Mohd. Rifai, Ilmu Fiqih Islam Lengkap, (Semarang: CV. Toha Putra, t.th), h. 402.

${ }^{18}$ Sayyid Sabiq, Fiqh Sunnah, Jilid IV, (Bandung, 2006), h. 45.

${ }^{19}$ Imam Ash-Shan'ani, Subulus Salam Juz. III, (Beirut : Darul Kutub Al-Ilmiyah, 1995), h. 23.

${ }^{20}$ Keputusan Menteri Keuangan Republik Indonesia. No. 304/KMK.01/2002.
} 
berlaku di pasar umat Islam pada masa lalu. Sebagaimana Umar bin Khathab juga pernah melakukannya demikian pula karena umat membutuhkan praktik lelang sebagai salah satu cara dalam jual beli. Jual beli secara lelang tidak termasuk praktik riba meskipun ia dinamakan bai' muzayadah dari kata ziyadah yang bermakna tambahan sebagai-mana makna riba, namun pengertian tam-bahan di sini berbeda. Dalam muzayadah yang bertambah adalah penawaran harga lebih dalam akad jual beli yang dilakukan oleh penjual atau bila lelang dilakukan oleh pembeli maka yang bertambah adalah penurunan tawaran. Sedangkan dalam praktik riba tambahan haram yang dimaksud adalah tambahan yang tidak diper-janjikan dimuka dalam akad pinjam-memin jam uang atau barang ribawi lainnya. ${ }^{21}$ Lebih jelasnya, praktik penawaran sesuatu yang sudah ditawar orang lain dapat diklasifikasi menjadi tiga kategori:

Pertama; Bila terdapat pernyataan eksplisit dari penjual persetujuan harga dari salah satu penawar, maka tidak diperkenan-kan bagi orang lain untuk menawarnya tanpa seizin penawar yang disetujui tawarannya. Kedua; Bila tidak ada indikasi persetujuan maupun penolakan tawaran dari penjual, maka tidak ada larangan syariat bagi orang lain untuk menawarnya maupun menaikkan tawaran pertama, sebagaimana analogi hadis Fathimah binti Qais ketika melaporkan kepada Nabi bahwa Mu'awiyah dan Abu Jahm telah meminangnya, maka karena tidak ada indikasi persetujuan darinya ter-hadap pinangan tersebut, beliau menawar-kan padanya untuk menikah dengan Usamah bin Zaid. Ketiga; Bila ada indikasi per-setujuan dari penjual terhadap suatu penawaran meskipun tidak dinyatakan secara eksplisit, maka menurut Ibnu Qudamah tetap tidak diperkenankan untuk ditawar orang lain. ${ }^{22}$ Syari' at tidak melarang segala jenis penawaran selagi tidak ada penawaran di atas penawaran orang lain ataupun menjual atas barang yang telah dijualkan pada orang lain. ${ }^{23}$

Telah dijelaskan di atas secara rinci tentang harga, bahwa harga mempunyai peranan penting dalam kegiatan ekonomi. Jual beli merupakan kegiatan ekonomi yang

${ }^{21}$ Ibnu Rusyd, Bidayatul Mujtahid Juz II, (Beirut Libanon,1992), h. 162.

${ }^{22}$ Asy-Syaukani, Nailul Authar Juz.V, (Beirut Libanon,1986), h. 191.

${ }^{23}$ Anonim. Lelang Syariah, http//www. lelang syariah.com diakse 25 Juli 2013. 
di dalamnya melibatkan transaksi antara penjual dan pembeli dengan menggunakan harga yang telah disepakati. Lelang merupakan suatu bentuk penjualan barang didepan umum kepada penawar tertinggi. Lelang dapat berupa penawaran barang tertentu kepada penawar yang pada mulanya mem-buka lelang dengan harga rendah, kemudian semakin naik sampai akhirnya diberikan kepada calon pembeli dengan harga ter-tinggi. Namun, dalam kegiatan jual beli banyak terjadi penyimpangan syariah baik pelanggaran hak, norma dan etika dalam jual beli tersebut dalam hal ini adalah praktik lelang. Maka, dalam penentuan harga di-lakukan oleh juru lelang atas per-mintaan penjual dengan melihat keadaan fisik barang lelang sebagai salah satu syarat pelelangan. Baik berupa harga naik maupun harga turun. ${ }^{24}$

Sebagaimana diketahui harga ditentu-kan oleh pasar, begitu pula dengan lelang yang dikenal dengan pasar lelang. Pasar lelang sendiri didefinisikan sebagai suatu pasar terorganisir, dimana harga menyesuai-kan diri terus menerus terhadap penawaran dan permintaan, serta biasanya dengan barang dagangan standar, jumlah penjual dan pembeli cukup besar dan tidak saling mengenal. Menurut ketentuan yang berlaku di pasar tersebut, pelaksanaan lelang dapat menggunakan persyaratan tertentu seperti sipenjual dapat menolak tawaran yang dianggapnya terlalu rendah yaitu dengan memakai batas harga terendah/cadangan (reservation price), biasanya disebut sebagai Harga Limit Lelang (HLL): bisa berupa Nilai Pasar Lelang (NPL) atau Nilai Minimum Lelang (NML). Sedangkan harga le--lang adalah harga penawaran tertinggi yang diajukan oleh peserta lelang yang telah disahkan sebagai pemenang lelang oleh Pejabat Lelang. ${ }^{25}$

Dalam praktek di Perusahaan Umum Pegadaian, lelang diartikan menjual barang jaminan gadai milik debitur yang tidak melunasi pinjamannya sampai batas waktu yang telah ditentukan dalam Surat Bukti Kredit (SBK) dan penjualan di muka umum oleh suatu panitia dengan aturan yang makin meningkat. Dari hal tersebut, hal-hal yang

\footnotetext{
${ }^{24}$ Aiyub Ahmad, op.cit., , h.73.

${ }^{25}$ Peraturan menteri keuangan tahun 2010 tentang petunjuk pelaksanaan lelang bab 1 pasal 27.
} 
pokok dalam pelelangan adalah barang tersebut harus di jual di muka umum dengan penawaran yang makin meningkat. Dan penawaran akan berhenti pada suatu saat di mana telah tercapai kesepakatan harga antara penjual dengan pembeli.

Untuk mengetahui macam-macam benda gadai yang dilelang, maka perlu diketahui pula benda yang diterima oleh Perusahaan Umum Pegadaian. Perusahaan Umum Pegadaian menerima benda gadai milik debitur sebagai jaminan berupa barang bergerak, seperti kain, emas, permata, sepeda, sepeda motor dan barang-barang elektronik lainnya. Di mana untuk barang-barang tersebut, disyaratkan masih dalam keadaan baik, yaitu tidak kurang dari $75 \%$ untuk dapat diterimanya sebagai benda gadai.

Benda gadai tersebut digolongkan menurut besar kecilnya jumlah pinjaman, yang dibagi menjadi 4 golongan sesuai dengan keadaan benda gadai yang dijamin-kan dan menurut harga yang ditetapkan oleh juru taksir. Menurut Surat Edaran Kepala Kantor Pusat Perusahaan Umum Pegadaian (SE NO. 27 tahun 1994) jangka waktu pinjaman untuk semua golongan adalah 120 hari. Sedangkan besarnya pinjaman masing-masing golongan ditentukan sebagai berikut:

a. Golongan A Rp. 5.000,00 sampai Rp. 40.000,00;

b. Golongan B Rp. 40.500,00 sampai Rp. 150.000,00;

c. Golongan C Rp. 151.000,00 sampai Rp. 500.000,00;

d. Golongan D pinjamannya di atas Rp. 500.000,00;

Untuk menetapkan besarnya suku bunga terdapat perubahan-perubahan yang disesuaikan dengan kondisi ekonomi dan besar kecilnya pinjaman. Perusahaan Umum Pegadaian dalam melaksanakan lelang ter-gantung pada benda-benda bergerak milik debitur yang tidak ditebus sampai jatuh temponya. Pelaksanaan lelang tersebut tidak dilakukan secara bersamaan, namun ber-dasarkan jangka waktu pinjaman. Untuk golongan A dan B akan dilelang pada awal bulan kedelapan terhitung mulai tanggal pemberian kredit. Sedang untuk golongan C dan D akan dilelang pada awal bulan kelima terhitung mulai saat pemberian kredit. 
Lelang merupakan salah satu akti-vitas operasional di Perusahaan Umum Pegadaian. Walaupun pada dasarnya Perusa-haan Umum Pegadaian sendiri tidak meng hendaki terjadinya lelang, akan tetapi tidak terlepas dari permasalahan lelang ini. Dalam Pasal 1154 KUH Perdata disebutkan bahwa:

"Apabila si berhutang atau si pemberi gadai tidak memenuhi kewajibannya, maka tidak diperkenankanlah si per-piutang memiliki barang yang di-gadaikan"26 Sedang dalam ayat (2) disebutkan "segala janji yang bertentangan dengan ini adalah batal". ${ }^{27}$

Dari ketentuan pasal tersebut dapat diartikan bahwa apabila debitur atau pemberi gadai wanprestasi, maka pemegang gadai, yang dalam hal ini Perusahaan Umum Pegadaian, tidak diperbolehkan memiliki barang jaminan. Jika si pemberi gadai atau debitur wanprestasi, menurut ketentuan Pasal 1155 ayat (1) KUHPerdata pemegang gadai berhak melelang barang jaminan tersebut. Adapun yang menjadi sebab-sebab debitur atau pemberi gadai tidak membayar hutangnya di lingkungan Perusahaan Umum Pegadaian adalah: ${ }^{28}$

a. Karena faktor ekonomi.

Pada saat yang telah ditentukan dalam Surat Bukti Kredit itu berakhir, keadaan perekonomian debitur tidak memungkinkan untuk membayar kembali pinjamannya. Sehingga akhirnya debitur merelakan barang nya yang dijadikan jaminan untuk dilelang. Faktor ekonomi inilah yang juga menye-babkan debitur datang ke Perusahaan Umum Pegadaian untuk meminjam uang, yang ber-akibat saat jatuh temponya habis ia tidak dapat mengembalikan uang pinjaman ter-sebut.

b. Faktor kelalaian petugas atau keter-batasan peralatan yang dimiliki oleh Perusahaan Umum Pegadaian.

\footnotetext{
${ }^{26}$ R. Subekti, R. Tjitrosudibio, Kitab Undang-undang Hukum Perdata, (Jakarta: PT. Pradnya Paramita, 1994), h. 249.

27 Ibid.

${ }^{28}$ Rochmat Somitro, Peraturan dan Instruksi Lelang, (Bandung: PT. Eresco, 1987), h. 160.
} 
Faktor tersebut merupakan faktor yang menentukan dalam keberhasilan suatu usaha di Perusahaan Umum Pegadaian. Apa-bila kedua faktor tersebut tidak atau kurang terpenuhi, maka akan mengakibatkan kurang nya efektivitas dalam melakukan suatu peker jaan. Dalam lingkungan Perusahaan Umum Pegadaian sendiri, karena keterbatasan per-alatan dan pengetahuan petugas, sedangkan jumlah nasabah begitu banyak, maka sering terjadi kekeliruan menentukan besarnya uang pinjaman. Oleh karena besarnya uang pinjaman yang diberikan tersebut keliru, yakni terlalu besar, sehingga menyebabkan debitur enggan untuk melunasi pinjamannya dan membiarkan barangnya yang dijadikan jaminan hutang dilelang.

c. Sering terjadinya debitur memakai perantaraan orang lain yang akhirnya merugikan nasabah itu sendiri. ${ }^{29}$

Meskipun dalam perundang-undangan sendiri membolehkan adanya pihak ketiga pemberi gadai, namun di lingkungan Peru-sahaan Umum Pegadaian tidak membenarkan adanya praktek calo tersebut. Namun dalam kenyataannya masih banyak debitur yang memakai jasa calo dalam memperoleh kredit di Perusahaan Umum Pegadaian, yang akhirnya merugikan nasabah itu sendiri, karena dengan adanya debitur yang memakai jasa calo tersebut Perusahaan Umum Pegadaian akan kesulitan untuk menghubungi pemilik barang yang sebenarnya, yang pada akhirnya barang tersebut terpaksa dilelang.

Dari uraian tersebut dapat disimpul-kan bahwa faktor utama yang menyebabkan terjadinya lelang adalah adanya wanprestasi oleh debitur, yang berupa 1) tidak memenuhi kewajiban atau perjanjian, baik sebagian maupun seluruhnya, 2) terlambat memenuhi kewajiban atau perjanjian, 3) Keliru atau tidak sempurna dalam memenuhi kewajiban atau perjanjian.

${ }^{29}$. Ibid. 


\section{PERSPEKTIF EKONOMI ISLAM TERHADAP PROSES HARGA LELANG BARANG JAMINAN}

Dalam konsep ekonomi Islam harga ditentukan oleh keseimbangan permintaan dan penawaran. Keseimbangan ini tidak akan terjadi jika di antara penjual dan pembeli tidak saling merelakan. Kerelaan ini ditentukan oleh penjual dan pembeli dalam mempertahankan kepentingannya atas bar ang tersebut. Jadi, harga ditentukan oleh kemampuan penjual untuk menyediakan barang yang ditawarkan kepada pembeli, dan kemampuan pembeli untuk mendapat-kan barang tersebut dari penjual.

Dalam kasus lelang permainan harga mulai menjadi tanding topic, konsep harga yang diusung adalah menggunakan nilai limit sebagaimana yang diatur dalam Peraturan Menteri Keuangan Nomor 93/Pmk. 06/2010 pasal 1 ayat 26. Hal ini

digunakan untuk membatasi harga terendah dalam pelelangan. Harga limit bisa berupa bisa berupa Nilai Pasar Lelang (NPL) atau Nilai Minimum Lelang (NML). Tujuannya untuk mencegah adanya trik-trik kotor berupa komplotan lelang (auction ring) dan komplotan penawar (bidder's ring) yaitu sekelompok pembeli dalam lelang yang bersekongkol untuk menawar dengan harga rendah, dan jika berhasil kemudian dilelang sendiri di antara mereka.

Dalam Pengamatan penulis mengenai proses lelang dan harga barang jaminan di Perum Pegadaian dan kemudian dianalisa menurut perspektif Ekonomi Islam, maka yang perlu diperhatikan dalam menganalisa proses lelang barang jaminan di Perum Pegadaian yaitu mengenai rukun, syarat, dan ketentuan umum jual beli.

1. Rukun Jual-beli

Adapun hal-hal yang terdapat pada proses lelang barang jaminan di Perum Pegadaian yang berkenaan dengan rukun jual-beli, adalah sebagai berikut:

a. Penjual dan Pembeli

Pelaksanaan lelang barang jaminan di Perum Pegadaian telah ditetapkan bahwa pihak yang melaksanakan lelang barang jaminan nasabah adalah pihak Pegadaian, dalam hal ini pihak pegadaian telah menunjuk pegawai sebagai petugas lelang. 
Pelaksanaan lelang akan terjadi apabila nasabah tidak dapat memenuhi kewajiban-nya sampai pada jatuh tempo, maka pihak pegadaian akan memberitahukan kepada nasabah bahwa barangnya akan dilelang kemudian nasabah dan pihak pegadaian menentukan harga barang tersebut setelah terjadi kesepakatan maka barang tersebut dilelang. Ketika terjadi proses lelang, pihak Pegadaian selaku pemegang kuasa berhak melaksanakan penjualan barang jaminan nasabah. Pembeli dalam proses lelang barang jaminan tersebut adalah masyarakat umum yang menjadi peserta lelang pada saat terjadinya proses lelang barang jaminan di Perum Pegadaian.

\section{b. Uang dan Benda}

Proses lelang barang jaminan tersebut dilakukan dengan sistem pembayar-an tunai. Sebelum petugas lelang melaksana-kan proses lelang, pihak pegadaian membertahukan kepada pihak nasabah terlebih dahulu untuk menentukan kesepakatan harga barang jaminan yang akan dilelang. Biasa-nya pihak pegadaian menetapkan harga minimum.

Harga minimum dari proses lelang tersebut ditentukan oleh pegadaian dengan menetapkan biaya minimum agar dapat menutupi pinjaman nasabah, Besarnya minimum pelelangan dihitung berdasarkan Jumlah Uang Pinjaman ditambah sewa modal dan Bea lelang. Selanjutnya dari harga minimum tersebut terjadi tawar menawar harga, harga tertinggi peserta lelang akan menjadi harga lelang, setelah ditetapkan oleh petugas lelang maka barang tersebut telah menjadi milik peserta lelang. Jika hasil lelang belum dapat menutupi uang pinjaman nasabah, maka nasabah masih mempunyai kewajiban untuk melunasinya. Begitu juga sebaliknya ketika hasil lelang mempunyai nilai lebih dari uang pinjaman nasabah, maka pihak Pegadaian akan mengembalikan kelebihanya.

c. Ijab dan qabul atau serah terima.

Dalam jual beli lelang barang jami-nan harus ada ijab dan qobul ditandai dengan pernyataan kehendak berupa harga yang ditawarkan oleh pihak pegadaian selaku penjual dan kesediaan oleh pembeli dengan satu harga yang mereka sepakati. Serah terima barang yang diperjual belikan dilakukan setelah terjadinya kesepakatan antara 
penjual dan pembeli, yang kemudian timbul kewajiban bagi pembeli untuk mem-bayar dan penjual menyerahkan barang tersebut.

2. Syarat Jual beli

Adapun syarat jual beli yang terkait dengan proses lelang barang jaminan di Perum Pegadaian adalah sebagai berikut:

a. Tentang Subjek

Mengenai syarat subjek dalam proses lelang barang jaminan tersebut dapat diketahui berdasarkan penjual dan pembeli yang telah baligh, berakal, dan atas kehendak sendiri. Pihak penjual dan pembeli harus memiliki pengetahuan, pengetahuan disini maksudnya adalah penjual dan pembeli mengetahui tentang proses jual beli yang akan dilakukan, dewasa dan mem-punyai kemampuan memilih karena tidak sah jual beli yang dilakukan oleh anak kecil yang belum nalar, orang gila atau orang yang dipaksa.

b. Tentang objek

1) Barangnya harus bersih

Bersih barangnya disini adalah terbebas dari najis maupun bebas dari golongan barang yang diharamkan. Sesuai dengan ketentuan tersebut maka barang jaminan di Perum Pegadaian hanya mene-rima barang bergerak seperti perhiasan, kendaraan, barang elektronik, alat rumah tangga dan barang lainnya yang dapat dinilai. Dapat diambil kesimpulan bahwa barang jaminan yang akan menjadi objek lelang di Perum Pegadaian merupakan barang bersih, bebas dari najis dan golongan dari barang yang diharamkan.

2) Dapat dimanfaatkan

Pemanfaatan barang jaminan di dapat dikategorikan sebagai barang yang memiliki nilai ekonomis, hal ini dilakukan oleh pegadaian sebagai dasar apabila nasabah tersebut tidak dapat memenuhi kewajibanya pada waktu yang telah ditentukan maka barang tersebut akan dilelang dan pada waktu terjadinya lelang barang jaminan 
tersebut tetap mempunyai nilai. Hasil lelang akan digunakan oleh pihak pegadaian untuk menutupi kewajiban nasabah yang tidak dapat memenuhinya.

3) Milik orang yang melakukan akad

Dikarenakan barang yang akan di-lelang merupakan milik nasabah yang hanya dijadikan barang jaminan, maka sebelum proses lelang terjadi, sebelumnya pihak pegadaian memberitahukan terlebih dahulu kepada nasabah. Pada saat terjadi proses lelang barang jaminan tersebut yang berhak melakukan adalah pihak pegadaian selaku pemilik kuasa barang jaminan milik nasabah. Sebelum terjadi pelelangan, antara nasabah dan pihak pegadaian telah menyepakati tentang kesepakatan harga barang jaminan yang akan dilelang.

4) Mampu menyerahkan barang yang akan dilelang

Pihak pegadaian selaku penjual dapat menyerahkan barang yang akan dijadikan objek lelang sebagai jual beli sesuai dengan harga yang disepakati

5) Mengetahui barang yang akan dilelang

Para pembeli dapat melihat secara langsung barang jaminan yang akan di-lelang, untuk menghindari unsur penipuan sebelum terjadi kesepakatan harga, barang jaminan tersebut ditimbang kembali pada waktu proses lelang. Mengenai pembayaran, peserta lelang akan mengetahui harga kesepakatan jual beli yang harus dibayar karena panitia lelang akan memberitahukan dan menyebutkan harga kesepakatan ter-akhir jual beli, kemudian pembeli membayar tanpa dikenakan biaya tambahan.

6) Barang yang diakadkan ada di tangan

Barang yang akan di lelang telah resmi berada pada penguasaan pihak pegadaian karena yang melaksanakan proses lelang adalah pihak pegadaian. Sedangkan harga barang lelang yang ditentukan di Perum Pegadaian Cabang Palopo, dihitung menurut jumlah taksiran barang sesuai dengan harga pasar setempat yang berlaku pada saat proses lelang.

c. Tentang Akadnya

Sebagaimana telah dijelaskan se-belumnya, bahwa jual beli dimuka umum atau lelang barang jaminan dilaksanakan dengan cara tawar menawar harga yang rendah 
kepada peserta lelang sampai memperoleh harga tertinggi dan lelang akan selesai ketika terjadi kesepakatan antara panitia lelang selaku penjual dengan peserta lelang selaku pembeli.

Proses Harga lelang barang jaminan di Perum Pegadaian telah terjadi persesuaian ketika adanya pernyataan yang dilakukan oleh panitia lelang selaku penjual dengan peserta lelang selaku pembeli yang menyata-kan kesediaannya untuk membeli barang jaminan tersebut. Dengan demikian proses lelang barang jaminan di Perum Pegadaian telah memenuhi rukun, syarat dan ketentuan umum jual beli. Terhadap syarat yang ditetapkan dalam akad, Islam memberikan kebebasan kepada pihak-pihak yang berakad untuk menetapkan syarat-syarat. Pihak yang melakukan akad bebas menenentukan syarat-syarat khusus pada waktu terjadi akad, selama syarat tersebut tidak menyalahi ketentuan syari’at.

Sejalan dengan perkembangan jaman, muncul pula pungutan lain yang kemudian dikenal dengan istilah pajak. Pajak adalah pungutan yang dilakukan oleh penguasa kepada rakyatnya untuk kepentingan umum atau Negara. Yang salah satunya adalah biaya lelang. Pada dasarnya biaya lelang dalam pelelangan yang ditetapkan pemerintah adalah bertujuan positif, yaitu turut menunjang pelaksaan program pemerintah di Bidang Ekonomi dan pengembangan nasional pada umumnya. Oleh karena itu telah menjadi kewajiban untuk menaatinya, selama ketentuan-ketentuan yang ditetapkan pemerintah mendatangkan kebaikan tidak mendatangkan kerusakan.

\section{PENUTUP}

Dalam Perspektif Ekonomi Islam lelang barang jaminan, dibolehkan dengan catatan menggunakan rukun jual beli, syarat jual beli dan ketentuan umum jual beli, mulai dari pemberitahuan kepada nasabah bahwa barang yang dijadikan sebagai jaminan telah melewati waktu jatuh tempo, pemberitahuan kondisi barang jaminan tersebut, persiapan lelang sampai dengan hasil pelelangan barang jaminan. Maka proses harga lelang barang jaminan terlaksana dan harus memenuhi kesepakatan persesuaian 
kehendak antara pihak penjual dan pihak pembeli. Adapun biaya lelang yang dibebankan pada pembeli bukan bertujuan untuk menaikan harga melainkan untuk kepentingan Negara yang dananya akan digunakan sebagai pajak. sedangkan dalam prosesnya jaminan gadai yang dilelang ditawarkan kepada nasabah yang lebih dulu melakukan kesepakatan dengan lembaga yang menaungi dalam hal ini pegadaian syariah.

\section{DAFTAR PUSTAKA}

Ahmad, Aiyub 2004. Fikih Lelang Perspektif Hukum Islam Dan Hukum Positif, Jakarta: Kiswah

Al-Jaziri, Syaikh Abdurrahman 1992Al-Fiqh 'Ala al-Madzahib Al-Arba'ah Juz. II, Beirut Libanon.

Alma, Buchari. t.th. Manajemen Pemasaran dan Pemasaran Jasa, Bandung : Alfabeta, t.th

Anto, M. B. Hendri.2003. Pengantar Ekonomi Islam, Yogyakarta: Ekonisia

Asy-Syaukani, 1986. Nailul Authar Juz.V, Beirut Libanon

Departemen Agama RI, 2004. Al-Qur'an dan Terjemahannya, Jakarta: PT. Syamil Cipta Media.

Dyana Harahap, Definisi Harga Menurut Islam, http://hargayangadil.blogspot.com/2011/02 /definisi-harga-menurutislam.html. diakses 20 September 2015.

Hidayah, Siti Muflikhatul. 2011. Penentuan Harga Jual Beli Dalam Ekonomi Islam, Surakarta FE.UMS.

Ibnu Rusyd, 1992. Bidayatul Mujtahid Juz II, Beirut Libanon

Imam Ash-Shan'ani, 1995. Subulus Salam Juz. III, Beirut: Darul Kutub Al-Ilmiyah,.

Islahi A. A., 1997. Konsepsi Ekonomi Ibnu Taimiyah, Jakarta: Bina Ilmu

Karim, Adiwarman Azwar. 2006. Sejarah Pemikiran Ekonomi Islam edisi ketiga, Jakarta: PT. Raja Grafindo Persada.

Keputusan Menteri Keuangan Republik Indonesia. No. 304/KMK.01/2002.

Muhammad, 2004. Ekonomi Mikro Dalam Perspektif Islam, Yogyakarta: BPFE,

Peraturan menteri keuangan tahun 2010 tentang petunjuk pelaksanaan lelang bab 1 pasal 27. 
Purnomo, Didit. 2005. Buku Pegangan Kuliah Kebijakan Harga (Pendekatan Agrikultural), Surakarta: FE- UMS.

Qardawi, Yusuf. 2003. Halal Haram Dalam Islam, Solo: Era Intermedia

Rifai, Mohd. t.th . Ilmu Fiqih Islam Lengkap, Semarang: CV. Toha Putra.

Sabiq, Sayyid 2006 Fiqh Sunnah, Jilid IV, Bandung. t.tp

Somitro, Rochmat. 1987. Peraturan dan Instruksi Lelang, (Bandung: PT. Eresco

Subekti, R. R. Tjitrosudibio, 1994. Kitab Undang-undang Hukum Perdata, (Jakarta: PT. Pradnya Paramita.

Syaefuddin, A. M. 1997. Islam untuk Disiplin Ilmu Ekonomi, Jakarta: Dirjen Lembaga Islam Depag RI

Tjiptono, Fandy. 1997. Strategi Pemasaran, Yoyakarta : Penerbit Andi 